IZA DP No. 7913

Unemployment Insurance and Underemployment Anna Godøy Knut Røed

January 2014 


\title{
Unemployment Insurance and Underemployment
}

\author{
Anna Godøy \\ Institute for Social Research \\ Knut Røed \\ Ragnar Frisch Centre for Economic Research \\ and IZA
}

Discussion Paper No. 7913
January 2014

IZA

P.O. Box 7240

53072 Bonn

Germany

Phone: +49-228-3894-0

Fax: +49-228-3894-180

E-mail: iza@iza.org

Any opinions expressed here are those of the author(s) and not those of IZA. Research published in this series may include views on policy, but the institute itself takes no institutional policy positions. The IZA research network is committed to the IZA Guiding Principles of Research Integrity.

The Institute for the Study of Labor (IZA) in Bonn is a local and virtual international research center and a place of communication between science, politics and business. IZA is an independent nonprofit organization supported by Deutsche Post Foundation. The center is associated with the University of Bonn and offers a stimulating research environment through its international network, workshops and conferences, data service, project support, research visits and doctoral program. IZA engages in (i) original and internationally competitive research in all fields of labor economics, (ii) development of policy concepts, and (iii) dissemination of research results and concepts to the interested public.

IZA Discussion Papers often represent preliminary work and are circulated to encourage discussion. Citation of such a paper should account for its provisional character. A revised version may be available directly from the author. 
IZA Discussion Paper No. 7913

January 2014

\section{ABSTRACT}

\section{Unemployment Insurance and Underemployment ${ }^{\star}$}

Should unemployment insurance (UI) systems provide coverage for underemployed job seekers? Based on a statistical analysis of Norwegian unemployment spells, we conclude that the answer to this question is yes. Allowing insured job seekers to retain partial UI benefits during periods of insufficient part-time work not only reduces UI expenditures during the part-time work period; it also unambiguously reduces the time until a regular selfsupporting job is found. Probable explanations are that even small temporary part-time jobs provide access to useful vacancy-information and that such jobs are used by employers as a screening device when hiring from the unemployment pool.

JEL Classification: $\quad$ C41, J65

Keywords: $\quad$ unemployment insurance, part-time work, duration analysis

Corresponding author:

Anna Godøy

Institute for Social Research

P. box 3233 Elisenberg

0208 Oslo

Norway

E-mail: a.a.godoy@socialresearch.no

\footnotetext{
* This research is part of the project "Social Insurance and Labor Market Inclusion in Norway", financed by the Norwegian Research Council (grant 202513). Data made available by Statistics Norway have been essential.
} 


\section{Introduction}

Should unemployment insurance (UI) systems provide coverage for underemployed job seekers, i.e., for persons who have some paid work, but would like to work more? Standard job search theory suggests that policy makers face a tradeoff; see, e.g., Ek \& Holmlund (2011): Offering partial UI benefits to parttime workers seeking fulltime employment reduces unemployment, as it becomes more attractive to substitute underemployment for unemployment and, hence, the set of acceptable jobs is expanded. But at the same time it also makes part-time work relatively more attractive compared to fulltime employment, potentially implying that fulltime employment declines.

UI programs targeted at partially unemployed workers are in some form operated in the majority of OECD countries (Cahuc \& Carcillo 2011, Hijzen \& Martin 2013). They serve two purposes; i) to reduce layoffs by allowing employers to temporarily reduce work-hours while compensating workers for the induced loss of income, and ii) to encourage unemployed job seekers to accept some work as a stepping-stone toward self-supporting employment, even when the job pays less (or just slightly more) than the UI benefit and thus presumably would be rejected in the absence of partial UI. The present paper examines the impacts of offering UI coverage to partially unemployed persons who were fully unemployed at the time of entry into the UI system. This implies that our focus lies on the role that partial UI benefits play in the return-to-work process via their impacts on employment opportunities, search effort, and choosiness. We do not examine the impacts of short-term work schemes on firms' layoff-strategies.

Offering unemployed job seekers the opportunity to combine UI benefits and some (part-time and/or short-term) work can be interpreted as a sort of active labor market program (ALMP) whereby claimants are incentivized to maintain contact with the labor market. This may be considered a goal in its own right, as labor earnings at least to some extent substitutes for UI benefits during the period with part-time employment. But it may also be viewed as a strategy for reducing the overall length of the job search period, as part-time and occasional work may serve as a stepping-stone toward fully self-supporting employment. This could be the case if employers use these jobs as a screening device for regular fulltime employment, if the job experience entails contacts/networks that make it easier to find other jobs, or if the work contributes to maintaining human capital. On the other hand, subsidized part-time employment may distract the job seeker from more productive job search activities and also raise reservation wages, as those who chose to combine part-time work and UI benefits presumably consider this to be a more attractive option than full unemployment. Thus, whether partial UI contributes to increasing or decreasing the overall duration of UI claims is essentially an empirical question.

On the basis of exceptionally rich Norwegian administrative data, the present paper examines the impact of obtaining a UI-subsidized part-time job on the duration and outcome UI spells. Since the obtainment of a part-time job is a

non-randomly assigned event, empirical assessment of its causal effects is subject to a serious endogeneity problem. We deal with this problem by means 
of a timing-of-events methodology (Abbring \& Van den Berg 2003) based on a multivariate mixed proportional hazard rate model. In order to shed light on the underlying causal mechanisms, we not only examine the duration until some regular work is obtained, but distinguish explicitly between transitions to "good" and "bad" jobs.

A novelty of our approach is that we seek to distinguish good from bad jobs not only on the basis of initial earnings or job duration, but on the basis of the much broader and longer term consequences of the job match in question, including its potential for providing a stepping stone for subsequent career advancements. We do this by defining job match qualities on the basis of realized earnings over a longer time period after the match (3 years in our main specification), regardless of the extent to which these earnings were directly related to first job obtained after unemployment.

UI subsidized part-time work is likely to raise reservation wages. This reduces the overall transition rate to regular work, but at the same time it tilts the relative employment transition rates toward good jobs. Part-time work may also raise the job offer arrival rate as the employment experience potentially triggers a regular job offer from the part-time employer and/or provide access to more information about other job vacancies. This increases the overall transition rate to regular work, but if temporary part-time work is more common in the "bad job" segment of the labor market, this tilts the relative employment transition rates back toward bad jobs. Hence, the effects on both the overall employment transition rate and on the ratio of god-job-to-bad-job transitions are theoretically ambiguous

Our paper relates closely to two existing studies that also examine the impact of partial UI receipt on UI duration on the basis of mixed proportional hazard rate models. The first is Kyyrä (2010), who based on Finnish data essentially find no significant impacts of UI-supported part-time work on the transition rate to regular unsubsidized work. Since the data used in this paper contains relatively few observations, however, statistical inference is seriously limited by large standard errors. The second is Kyyrä et al. (2013) who based on Danish data identify a sharp decline in the transition rate to fulltime employment as job seekers move into UI-supported part-time work. After the return to full unemployment, however, there is a positive impact of having had some parttime work, suggesting that there is a favorable stepping-stone effect. Hence, the latter study indicates that there is indeed a tradeoff involved - between a negative lock-in effect during the period of part-time work and a positive stepping-stone effect afterwards. Kyyrä et al. (2013) conclude that the net effect on UI duration is positive for some groups and negative for others.

The present paper adds to the existing literature by building on an extraordinarily flexible statistical model, which not only treats transitions to good and bad jobs as distinct events, but also models the use of partial UI benefits jointly with the use of other (alternative or supplementary) policy instruments (ALMPs and UI sanctions). In addition, we take into account that a significant fraction of UI spells do not end in a transition to self-supporting employment at all, but rather in a transition to an alternative social insurance program (social 
assistance or temporary/permanent disability insurance).

In the present paper, partial employment is found to unambiguously reduce the time to find unsubsidized regular employment. That is, both post-program and on-program effects of working part time during job search are positive. We find no sign of lock-in effects. In an extended model, this seems to be driven to a large extent by transitions in the first month of part-time work. The increase is estimated to be positive for all transitions to employment, though larger for bad jobs than for good jobs.

The rest of the paper is organized as follows: Section 2 describes the data used in the analysis. The econometric model is formulated in section 3 , and identification is discussed in section 4 . Section 5 presents key estimates from our model, and section 6 concludes the paper.

\section{Data and institutional background}

The Norwegian UI system is universal, with individual eligibility based on earnings history prior to job loss. The replacement rate is $62.4 \%$ (capped at high earnings). In general, maximum UI duration is 2 years. For unemployed job seekers with low earnings prior to entering unemployment, maximum duration may be shorter (1 year). However, the sample will be constructed so that all individuals are entitled to 24 months UI. Persons whose previous employment and earnings history make them eligible for unemployment insurance can work part time and still receive benefits as long as their working hours are cut by at least $50 \%$, provided that they search actively for more work. That is, workers are able to receive partial benefits while working as long as their working hours are less than half of what they were before the job loss. Taking up partial benefits rather than remaining full time unemployed does not affect the maximum UI duration.

Our main source of data is monthly records on registered unemployment. When constructing the sample, data on registered unemployment is linked to data on jobs, annual earnings and demographics. The starting point in constructing the sample is all new full time unemployment spells with unemployment benefits, starting between January 2003 and December 2007. To ensure that our claimants start out with a full two-year maximum UI benefit period, we restrict the sample to individuals who were neither unemployed nor registered in education the last 12 months before entering unemployment, and who satisfied the income requirements for UI eligibility. Restricting the sample population in this way ensures that every unemployed person entering the sample is eligible for unemployment benefits for a full 24 month period.

In the first month of each spell, all job-seekers are by definition on full time unemployment, receiving benefits. In later months, those still looking for work can be in one of three mutually exclusive states: full time unemployment, part time unemployment, or participating in an active labor market program (ALMP). Similarly, each month we observe whether they receive unemployment benefits. Temporary benefit loss can happen for a variety of reasons, such as 
a sanction if workers refuse to participate in activities or accept a suitable job offer, or when the person is sick or on vacation. Part-time unemployed workers will lose their benefits in periods when hours worked in their part time job exceeds $50 \%$ of hours in their old job.

In constructing the spells, a person is considered as leaving unemployment once they leave registered unemployment altogether and do not re-enter for at least three months. Interruptions from unemployment lasting three months or less are censored, such that the spells continue when they return to unemployment (not including the missing moths).

Exits from unemployment are classified as either exits to employment or to other social insurance programs, primarily social assistance and health related benefits. Transitions out of unemployment are classified as exits to employment only if the individual can be linked to a job in the employer-employee register with a recorded starting date between 30 days before exit from unemployment and 60 days after exit from unemployment. Exits from unemployment that cannot be classified into either category will be treated as right-censored.

Next, the unemployment spells are merged with individual characteristics that are thought to influence the job search process. For each individual, we attach data on age, gender, household size and number of kids under 18. Only people aged 25-55 are retained in the sample. The dataset includes dummies for family status (married, with or without children, cohabiting with joint children, unmarried with/without kids). Education is included as a set of dummy variables: compulsory education only, some high school, high school graduates, some college, undergraduate degree, graduate degree $(\mathrm{MA}$ or $\mathrm{PhD})$ and education unknown. As additional control variables, we include pre-unemployment earnings and indicators of personal liquidity (based on bank deposits) and a dummy for those qualifying for extended unemployment benefits. During parts of the data period, unemployed workers with a strong labor market attachment were eligible to continue receiving benefits after the maximum UI duration was reached, although at a significantly lower replacement rate.

For workers who make a transition to employment, we attach data on later earnings. We wish to use these earnings to classify the job as high or low quality employment. What we are after is a measure of whether the person who made the transition had higher or lower earnings over a period after the transition than could reasonably be expected, given their observed and unobserved qualifications. If these "reasonable" earnings thresholds were directly observable, we could do a simple comparison of realized versus expected earnings and the classification of good and bad jobs would be trivial.

Instead, we use a two step procedure to empirically identify job quality using only observables. For this purpose we take advantage of an additional dataset containing information on annual earnings, educational attainment and years of labor market experience for all Norwegian workers. The auxiliary sample contains the full population of persons aged 25-55 whose labor earnings are consistent with full time employment - using an earnings threshold equivalent to 21,604 USD in 2007. The sample includes data from 7 years (2004-2010) representing $2,183,528$ individuals in a total of 11,456,468 person-year observations. 
Based on this sample, we estimate:

$$
w_{i t}=e e_{i t} \beta^{e e}+e d_{i t} \beta^{e d}+\left(e e_{i t} \times e d_{i t}\right) \beta^{i n t}+y r_{i t} \beta^{y r}+\varepsilon_{i t}
$$

where $w$ is log annual earnings, $e e$ is employment experience, $e d$ is education and $y r$ is calendar time. Education is here measured in terms of 61 categorical variables (reflecting level and field), calendar time is represented with one dummy for each year and employment experience is a scalar (number of years in employment). The estimated model is then used to compute predicted annual earnings

$$
\bar{w}_{i t}=E\left[w_{i t} \mid e e_{i t}, e d_{i t}\right]
$$

for all the job seekers in our unemployment analysis population.

Then, we compare these predicted earnings with the earnings actually achieved by the persons moving into employment in our unemployment sample. In our main specification, we measure earnings over a three year period. For a person $i$ finding a job in year $t$, we compute

$$
\hat{\varepsilon}_{i}^{3}=\frac{1}{3} \sum_{s=1}^{3}\left(w_{i t+s}-\bar{w}_{i t+s}\right)
$$

This measure - average residual earnings over the first three years after exiting unemployment - is the basis for assessing job quality. This measure is a global measure of labor market success that will reflect both the initial wage level, the stability of employment and the extent to which the job offered opportunities for further career advancements.

Next, we divide all job transitions into two equally large groups, classifying jobs as high quality if the residual wage is above the sample median, and low quality otherwise. So, by definition, the two job types will be equally likely on average.

The sample consists of 27,403 spells, representing 27,294 persons counting a total of 251,604 person-month observations. The fact that so few persons are registered with two or more spells probably reflects the selection criteria where we condition on no prior unemployment experience in the two years before entering the sample. Table 1 presents some summary statistics of these spells.

Although maximum benefit duration is 24 months for all workers in the sample, the average spell duration is considerably shorter at 8.08 benefit months used at end of spell. Just 5 percent of spells ever reach benefit exhaustion.

Subsidized part time work is fairly common: 46 percent of all spells have at least one month of partial benefits. Subsidized part time work is more common among women than men, and more common among persons who worked part time before entering unemployment. Job-seekers who have one or more period of partial employment appear to be largely similar to the rest of the sample in terms of age, education, family status and personal liquidity.

Subsidized part time work is associated with longer unemployment durations, and a higher share of spells reaching benefit exhaustion. Persons who at some point work part-time during the unemployment spell are more likely 
Table 1: Summary statistics, by partial employment status

\begin{tabular}{lccc}
\hline \hline & $(1)$ & $(2)$ & $(3)$ \\
& $\begin{array}{c}\text { All spells } \\
\text { mean }\end{array}$ & $\begin{array}{c}\text { No partial UI } \\
\text { mean }\end{array}$ & $\begin{array}{c}\text { With partial UI } \\
\text { mean }\end{array}$ \\
\hline Age & 37.29 & 37.00 & 37.64 \\
Female & 0.51 & 0.45 & 0.58 \\
Married, no kids & 0.07 & 0.07 & 0.08 \\
Married, with kids & 0.38 & 0.37 & 0.38 \\
Cohabiting & 0.11 & 0.11 & 0.11 \\
Single, with kids & 0.08 & 0.07 & 0.09 \\
Single, no kids & 0.36 & 0.38 & 0.34 \\
Number of children if children present & 1.73 & 1.72 & 1.73 \\
Only compulsory education & 0.35 & 0.32 & 0.39 \\
Secondary education & 0.56 & 0.57 & 0.54 \\
Higher education & 0.09 & 0.10 & 0.07 \\
Education unknown & 0.00 & 0.00 & 0.00 \\
Qualified for continued benefits & 0.70 & 0.65 & 0.75 \\
Low liquidity & 0.50 & 0.49 & 0.50 \\
Old job was part time (if old job known) & 0.21 & 0.12 & 0.31 \\
Benefit months used at end of spell & 8.08 & 5.99 & 10.47 \\
To benefit exhaustion & 0.05 & 0.02 & 0.09 \\
Ever temp. benefit stop & 0.25 & 0.12 & 0.40 \\
Ever on partial benefits & 0.46 & 0.00 & 1.00 \\
Ever on ALMP & 0.19 & 0.16 & 0.22 \\
To employment, restrictive definition & 0.45 & 0.49 & 0.41 \\
Other benefit & 0.09 & 0.09 & 0.08 \\
Still ongoing Dec. 2007 & 0.08 & 0.09 & 0.08 \\
Good job, 1 year & 0.50 & 0.52 & 0.47 \\
Good job, 3 year & 0.50 & 0.53 & 0.47 \\
New job is part time (if job is known) & 0.19 & 0.11 & 0.30 \\
New job is part time (From full time) & 0.11 & 0.07 & 0.18 \\
New job is part time (From part time) & 0.49 & 0.41 & 0.53 \\
\hline Observations & 27403 & 14664 & 12739 \\
\hline \hline
\end{tabular}

Note: Table shows summary statistics of all spells; column 2 represents spells with no episodes of part-time work and column 3 represents spells with at least one episode of part-time work during the period of registered unemployment. 
Figure 1: Exit rates to employment, by partial benefit status

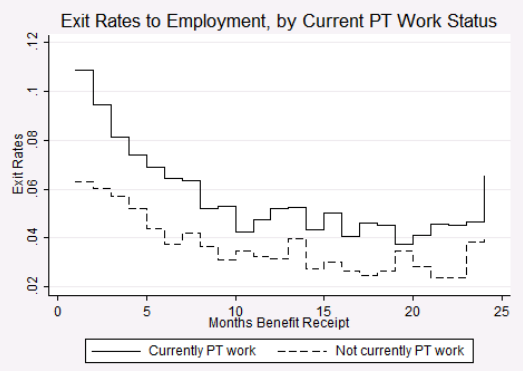

(a) To employment, current recipient

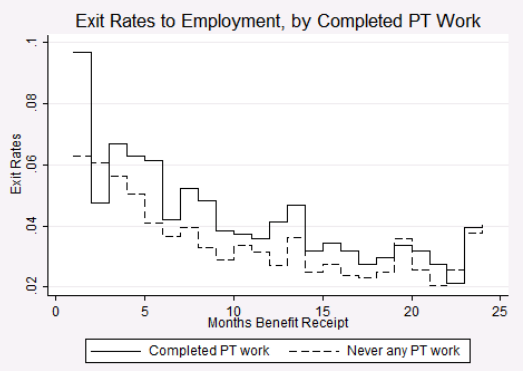

(b) To employment, previous recipient

Note: Figure shows empirical exit rates to employment by UI duration. In panel (a), the solid line represents exit rates for partially employed job-seekers while the dashed line plots exit rates for other job-seekers. In panel (b), the solid line represents exit rates for full time unemployed job-seekers who have completed one or more month of partial employment, and the dashed line plots exit rates for other full time unemployed job seekers (underemployed job-seekers currently working part-time are not represented in the figure in panel (b)).

to have at least one period of temporary benefit loss. This could be due in part to their longer total unemployment duration, and in part that they would lose their benefits when hours worked in their part-time job exceed $50 \%$ of preunemployment hours. Still, a majority of these spells never include any temporary stops in unemployment benefits, indicating that most part-time work is in fact subsidized. With our definition of transitions to employment, only about $45 \%$ of spells end with a transition to work. People who have never been partially employed are more likely to make a transition to employment, and conditional on getting a job they are also just slightly more likely to end up in a high quality job.

To get a first impression of the correlation between partial benefit status and exit rates to employment (regardless of job quality), empirical exit rates to employment are computed by total months of UI receipt. Computed exit rates are plotted in Figure 1: panel (a) shows exit rates by current partial employment status, while panel (b) plots exit rates by previous partial employment status. For all categories of workers, exit rates tend to fall with spell duration, rising slightly towards the end of the maximum eligibility period. Underemployed jobseekers have higher exit rates than the full-time unemployed, especially at lower benefit durations. Exit rates for people who have finished one or more spell of subsidized part time work appear to be quite similar, perhaps with slightly higher transition rates, compared to the rest of the sample.

For $41 \%$ of spells involving one or more month of subsidized part time work, we are able to link the part-time job to an employer in the employer-employee register. In $79 \%$ of exits to employment with some prior subsidized part time work, the part-time employer and the eventual employer in the regular job are 
identical. Looking only at transitions directly from partial employment, 85\% of job exits are to the same employer, suggesting that some firms use part-time work as a way of screening new workers when hiring from unemployment.

\section{$3 \quad$ Econometric model}

We set up a competing risks model of unemployment durations. We model six transitions, indexed by $k=1, \ldots, 6$ :

1. to high quality employment

2. to low quality employment

3. participation in active labor market program

4. partial employment while still receiving partial benefits

5. to other benefits (sickness benefits, disability, social assistance)

6. for workers on partial benefits: return to full time unemployment

Events 1,2 and 5 terminate the unemployment spell. Participation in active labor market programs and receiving partial benefits do not terminate the unemployment spell. Current and past participation in these programs is allowed to have causal effects on all other transitions. For persons in subsidized parttime employment, the return to full employment is modeled as an endogenous event, to ensure that our causal estimates are not biased by selectivity in the durations of part-time jobs. The duration of ALMP participation is assumed to be predetermined (unless a job is found), so transitions from ALMP back to full time unemployment are not modeled as endogenous events. The model is illustrated in Figure 2, where the solid arrows represent the modeled transitions.

Formally, let $\lambda_{k i t}$ be individual $i$ 's hazard rate for event $k$. We assume hazard rates are proportional in observed and unobserved characteristics. Employment status is observed monthly, so we write the model in terms of grouped integrated hazard rates. Assuming the underlying continuous time hazard rates are constant within each month, we define the monthly integrated hazard rates $\theta_{\text {kit }}$ as functions of observable and unobservable individual characteristics

$$
\theta_{k i t}=\int_{t-1}^{t} \lambda_{k i s} d s=\exp \left(\phi_{k i t}+v_{k i}\right)
$$

where $\phi_{k i t}$ is an index function of (possibly time varying) observables and $v_{k i}$ is unobserved individual characteristics, assumed to be constant over time.

The index function $\phi_{k i t}$ is defined as

$$
\phi_{k i t}=\beta_{k t}^{q} q_{i t}+\beta_{k d t}^{d} d_{i t}+\beta^{z} z_{i t}+\beta_{k}^{r} r_{i t}+\beta_{k}^{x} x_{i t}, k=1, \ldots, 6
$$

$d_{i t}$ are dummies for UI duration, measured by months of unemployment benefit receipt. We use months with UI claims as our fundamental duration 
Figure 2: Modeled transitions

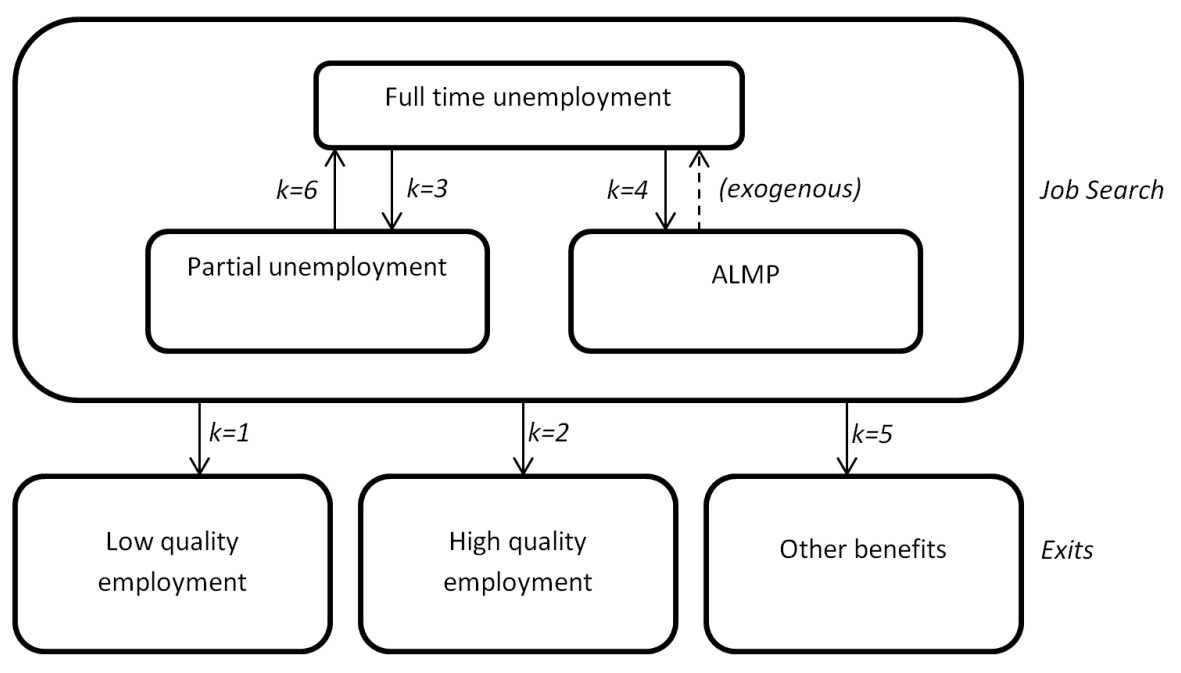

concept, implying that the "duration-clock" is stopped in periods without UI benefits (due, to, e.g., sanctions or program participation). At the point of UI exhaustion after 24 UI months, all spells are right-censored. The reason for this is that the termination of UI entitlements implies the removal of the main incentive to register at the employment office and thus a significant drop in data reliability.

$z_{i t}$ is an indicator of a cut in benefits before before benefit exhaustion. Such temporary cuts are not modeled as endogenous events, and thus estimates of $\hat{\beta}^{z}$ should not be given a causal interpretation.

$r_{i t}$ is a vector of four dummies indicating ongoing or completed participation in ALMP or partial benefits, capturing on-program and post-program effects of interventions. $q_{i t}$ are monthly time dummies.

$x_{i t}$ is a vector of observables: gender, age (dummy-coded), education (dummycoded, 7 groups), family type (married, cohabiting, single, with or without kids), household size, log annual earnings before entry to unemployment, and a set of indicators of low liquidity and qualifications for extended unemployment benefits.

The unobserved covariate $v_{k i}$ is a time-invariant scalar variable summarizing individual $i$ 's intrinsic propensity to make a transition of type $k$. Since there are six events, each person is characterized by a six-dimensional unobserved heterogeneity vector. We do not impose any restrictions on the way these unobservables are correlated. We estimate the joint distribution nonparametrically along the lines suggested by Heckman \& Singer (1984), and further developed by Gaure et al. (2007). This implies that we add new support points and location vectors to the hetereogeneity distribution until it is no longer possible 
to increase the likelihood function. Our estimation algorithm also deals with the potential left-truncation problem arising from our monthly point-in-time sampling schedule, implying that very short spells - those starting and stopping between two observation posts - are lost from the sample; see Gaure et al. $(2007)^{2}$. The likelihood function is presented in Appendix A.

\section{Identification}

The model presented in the previous sections raises some rather intricate identification issues related to the disentanglement of causal effects from potential sorting on unobserved heterogeneity. In particular, we need to ensure that our estimates regarding duration dependencies and the impacts of part-time work and participation in ALMPs really captures the presumed causal effects, and not the selectivity associated with the already realized events.

For the mixed proportional hazard rate model that we use in the present paper, the causal impacts of spell duration and of endogenous events have been shown to be non-parametrically identified, provided that some regularity conditions are met; see Van den Berg (2001) and Abbring \& Van den Berg (2003). Identification then relies on a no-anticipation assumption, requiring that individuals do not foresee and act ex ante upon the realization of the stochastic process determining future events. The causal parameters of primary interest in our case are those representing the on-treatment and post-treatment effects of obtaining a part-time job with partial UI benefits. The no-anticipation assumption will be violated if, say, an unemployed job seeker is informed that a part-time job will be available at some specific time in the future, and at the same time responds to this information by changing job search behavior immediately. While we cannot rule out such violations, we find it hard to believe that they are empirically important in our context. Both part-time jobs and ALMP slots typically become available at very short notice, and are implemented quickly once the relevant decisions have been made. Note also that the no-anticipation-assumption does not rule out behavioral responses towards changes in event probabilities insofar as these are captured by the systematic part of the model.

While the standard identification results referred to above rely heavily on the proportional hazards assumption, it has been shown in the literature that the proportionality assumption can be relaxed if there is sufficient time-variation in the explanatory covariates (McCall 1994, Brinch 2007). The intuition behind this result is that time-varying covariates provide implicit "exclusion restrictions" in the sense that past values of these variables are assumed to have no direct causal effects (conditional on their current values), and therefore correlate with current outcomes only via the sorting process. Of particular value for identification in our case is the substantial calendar time variation in both labor

${ }^{2}$ The optimization algorithm is further
http://www.frisch.uio.no/NPMLE.html and available for
http://folk.uio.no/sgaure/ubuntu/


market tightness (providing time variation in transitions to the two employment states as well as to part-time work) and in the scale of labor market programs (providing time-varying in the transition to ALMPs), which we capture in the most flexible way possible; i.e., by means of a large number of calendar time dummy variables.

\section{Results}

All explanatory variables are included in all transitions except where it's logically impossible, e.g. current participation in ALMP is not included in the hazard rate for ALMP participation. The final model contains 859 parameters to be estimated, not counting the parameters of the distribution of unobserved heterogeneity. The model is estimated by maximum likelihood, adding mass points to the distribution of $v$ until it is no longer computationally feasible to add more. The preferred model is the one with the highest number of mass points unless there is a model specification with fewer mass points with a lower Akaike Information Criterion (AIC). The preferred model has 18 mass points in the distribution of unobserved heterogeneity, meaning that we estimate an additional 125 parameters of the unobserved heterogeneity distribution.

Table 2: Main Model: Selected Estimates

\begin{tabular}{lcccccc}
\hline \hline & $(1)$ & $(2)$ & $(3)$ & $(4)$ & $(5)$ & $(6)$ \\
Variable & Good Job & Bad Job & PT Work & ALMP & Other Ben & To FTU \\
\hline PT Work (on) & $1.256^{* * *}$ & $1.85^{* * *}$ & & $.641^{* * *}$ & $.701^{* * *}$ & \\
& $(3.275)$ & $(7.248)$ & & $(-7.689)$ & $(-3.205)$ & \\
PT Work (post) & 1.105 & $1.396^{* * *}$ & $2.409^{* * *}$ & $.845^{* * *}$ & 1.056 & \\
& $(1.4)$ & $(3.882)$ & $(22.272)$ & $(-3.4)$ & $(.634)$ & \\
ALMP (on) & $.634^{* * *}$ & $.554^{* * *}$ & $.71^{* * *}$ & & $.385^{* * *}$ & \\
& $(-4.053)$ & $(-4.997)$ & $(-7.269)$ & & $(-7.622)$ & \\
ALMP (post) & $1.491^{* * *}$ & 1.11 & $1.486^{* * *}$ & $.822^{* * *}$ & .872 & $.791^{* * *}$ \\
& $(3.882)$ & $(1.036)$ & $(8.984)$ & $(-2.808)$ & $(-1.326)$ & $(-4.188)$ \\
No Ben. & $1.963^{* * *}$ & $2.287^{* * *}$ & $.857^{* * *}$ & $.81^{* * *}$ & $7.288^{* * *}$ & $.703^{* * *}$ \\
& $(12.71)$ & $(15.868)$ & $(-3.676)$ & $(-3.009)$ & $(29.907)$ & $(-9.282)$ \\
Female & $.688^{* * *}$ & $1.081^{*}$ & $1.323^{* * *}$ & $.823^{* * *}$ & 1.018 & $.668^{* * *}$ \\
& $(-9.037)$ & $(1.797)$ & $(10.408)$ & $(-5.906)$ & $(.292)$ & $(-11.396)$ \\
Ln(w0) & $4.821^{* * *}$ & $.518^{* * *}$ & $.696^{* * *}$ & .93 & $.676^{* * *}$ & $1.107^{*}$ \\
& $(20.238)$ & $(-8.566)$ & $(-9.41)$ & $(-1.489)$ & $(-4.268)$ & $(1.898)$ \\
\hline \hline
\end{tabular}

Note: Table shows selected estimates from model with 18 mass points in the distribution of unobserved heterogeneity. Exponentiated coefficients, t-values in parentheses. Transitions to employment classified as "good job" when average residual earnings the first three years after leaving registered unemployment are above the sample median, and "bad job" otherwise. "Other Ben." include transitions to rehabilitation benefits, long term sick leave, disability pensions and social assistance. "To FTU" refers to transitions from partial employment to full time unemployment. "No ben." is an indicator of temporary stop in benefits. Additional controls: age, family status, education, calendar time, liquidity, qualification for extended benefits.

Table 2 contains selected estimated effects, in the form of exponentiated parameter estimates (with t-values in parentheses). These numbers represent 
the proportional shifts in the hazard rates generated by unit changes in the explanatory variables. For example, the number 1.256 in the upper left-hand cll indicates that ongoing part-time work raises te hazard rate to a good job by $25.6 \%$, ceteris paribus. The full estimation results (in the form of parameter estimates with standard errors) can be found in Appendix B.

Columns 1 and 2 of Table 2 present estimated effects on transitions to employment. The model finds positive effects of subsidized part-time employment on transitions to regular employment both during and after part-time employment. Both instant and delayed effects are larger for transitions to bad jobs. Ongoing part time work increases the hazard rate to good jobs by around 26 percent, while the hazard rate to bad jobs increases by 85 percent relative to the baseline. While the estimated post-program effect is positive for both job types, the effect is only significant for transitions to low quality jobs ( $39.6 \%$ increase). The effect for high quality jobs is smaller and not statistically significant.

In this model, ALMP appears to have negative effects on transitions to employment during participation, but positive effects afterwards. The model identifies strong lock-in effects of ongoing ALMP both to high and low quality employment; hazard rates are reduced by $37 \%$ and $55 \%$ respectively. Post-ALMP the hazard rate to good jobs increases by $49 \%$, while there is no significant increase in the hazard to bad jobs.

Figure 3 shows estimated duration dependence for the 6 modeled transitions, with all hazards normalized to unity in the first month. The hazard to partial unemployment drops off quickly early in the unemployment spell and then stays flat. The ALMP hazard rises nearly linearly during the first 8 months of benefit receipt. The transition rate out of registered unemployment to other benefits exhibits positive duration dependence, rising dramatically towards the end of the unemployment benefits eligibility period.

The duration dependence of the employment hazard rate differs depending on job quality. To better see this, Figure 4 presents the point estimates in a common graph. The hazard rate of transitions to low quality jobs rises slightly throughout the first 22 months of benefit receipt, then jumps significantly as benefit exhaustion approaches. The hazard rate for high quality employment on the other hand falls during the first 22 months duration, then rises somewhat toward the end of the UI period, though the jump is small compared to that for bad jobs. That is, when distinguishing between transitions to good and bad jobs, the peak in the job finding hazrd rate at benefit exhaustion is almost entirely driven by transitions to poor jobs, defined as the $50 \%$ of job transitions where residual earnings first three years after exit to work are below the sample median (cf. section 2).

Finally, we consider the estimated distribution of unobserved heterogeneity parameters to shed some light on selection on unobservables. Table 3 contains estimated correlations between (exponentiated) random coefficients. The estimated correlation in unobserved heterogeneity terms for poor jobs and part-time work is negative $\left(\rho_{1,3}=-0.107\right)$, while the estimated correlation between good jobs and part-time work during job search is positive $\left(\rho_{2,3}=0.1022\right)$.

To shed further light on the role of unobserved heterogeneity, Table 4 con- 
Figure 3: Model transitions

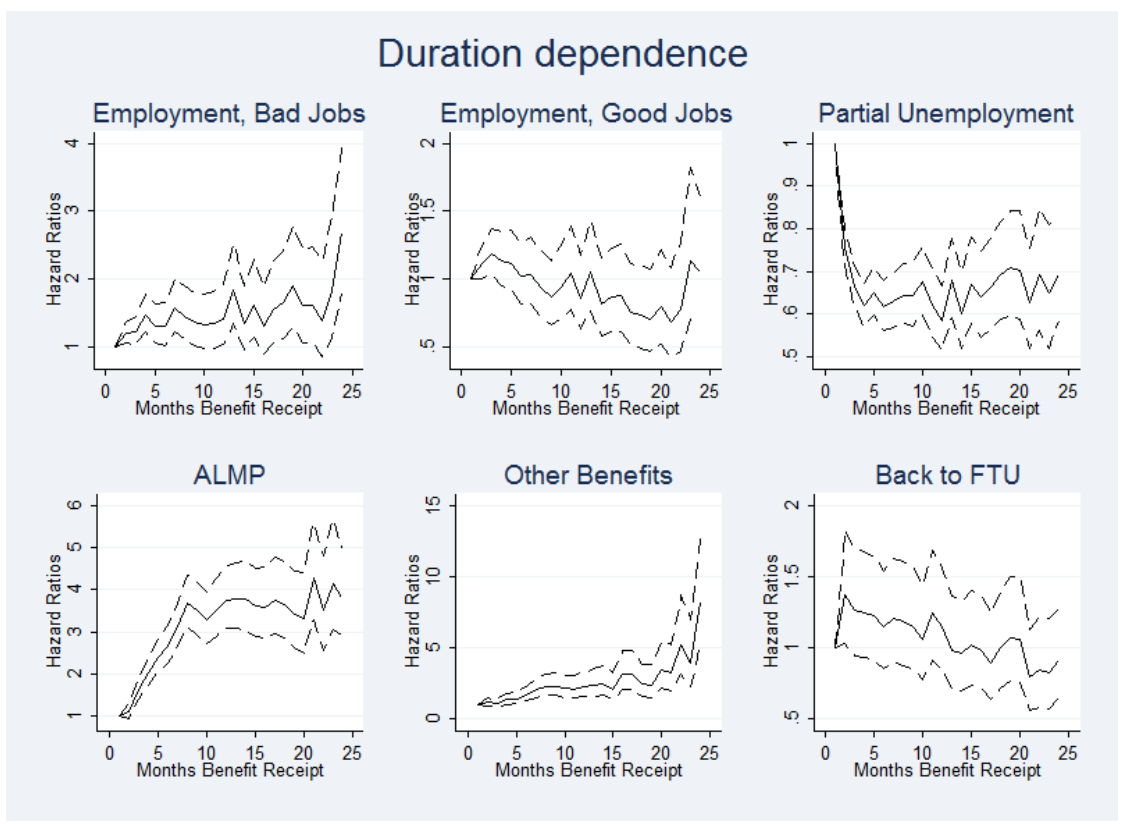

Note: Figure plots estimated duration dependence for the 6 modeled transitions with $95 \%$ confidence intervals. Exponentiated coefficients plus minus 2 standard deviations. Preferred model specification with unobserved heterogeneity (18 mass points). All spells treated as censored after benefit exhaustion.

Table 3: Estimated correlations between random coefficients

\begin{tabular}{lccccc}
\hline \hline$k / k$ & 1 & 2 & 3 & 4 & 5 \\
\hline 2 & .2084 & & & & \\
3 & -.107 & .1022 & & & \\
4 & .0357 & .0998 & -.268 & & \\
5 & -.043 & -.064 & .1893 & .0683 & \\
6 & -.185 & -.197 & -.384 & .0883 & -.004 \\
\hline \hline
\end{tabular}

Note: Table shows estimated correlations between random coefficients $(\exp (v))$ in the preferred model specification with 18 mass points in the distribution of $v$. 
Figure 4: Duration dependence - employment

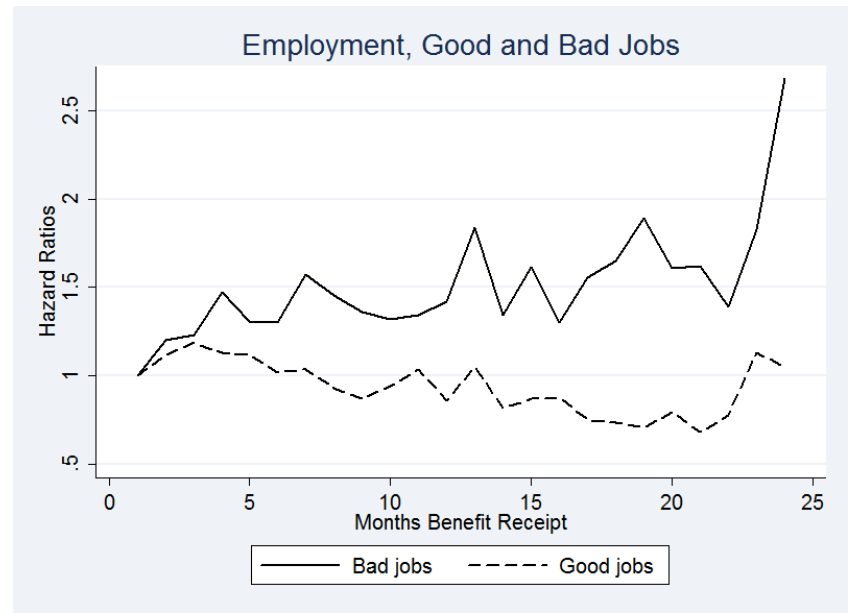

Note: Figure plots estimated duration dependence for transitions to good and bad jobs, as defined by average residual earnings the first three years following transition to work. Exponentiated coefficients from the preferred model specification with unobserved heterogeneity (18 mass points). All spells treated as censored after benefit exhaustion.

Table 4: No unobserved heterogeneity

\begin{tabular}{lcccccc}
\hline \hline & $(1)$ & $(2)$ & $(3)$ & $(4)$ & $(5)$ & $(6)$ \\
Variable & Good Job & Bad Job & PT Work & ALMP & Other Ben & To FTU \\
\hline PT Work (on) & $1.58^{* * *}$ & $1.551^{* * *}$ & & $.419^{* * *}$ & $.564^{* * *}$ & \\
& $(13.379)$ & $(13.138)$ & & $(-22.565)$ & $(-10.269)$ & \\
PT Work (post) & $1.353^{* * *}$ & $1.366^{* * *}$ & $4.045^{* * *}$ & $.813^{* * *}$ & 1.083 & \\
& $(6.497)$ & $(6.875)$ & $(78.701)$ & $(-5.267)$ & $(1.271)$ & \\
ALMP (on) & $.659^{* * *}$ & $.642^{* * *}$ & $.6^{* * *}$ & & $.423^{* * *}$ & \\
& $(-5.57)$ & $(-6.05)$ & $(-15.103)$ & & $(-8.842)$ & \\
ALMP (post) & $1.345^{* * *}$ & $1.213^{* * *}$ & $1.094^{* * *}$ & $1.228^{* * *}$ & .969 & $1.196^{* * *}$ \\
& $(5.679)$ & $(4.124)$ & $(3.74)$ & $(5.404)$ & $(-.451)$ & $(6.28)$ \\
\hline \hline
\end{tabular}

Note: Table shows selected estimates from model with 1 mass point. Exponentiated coefficients, t-values in parentheses. 
tains estimated effects for the model estimated with a single mass point in the distribution of $v$, i.e. a model without unobserved heterogeneity. While the preferred model specification with 18 mass points found significant differences in the effects of partial employment on transitions to good and bad jobs, in the model with 1 mass point partial employment appears to affect transitions to high and low quality employment equally. Specifically, ignoring unobserved heterogeneity, ongoing partial benefits increase the employment hazard to good and bad jobs by 58 and $55 \%$. That is, accounting for unobserved heterogeneity reduces the estimated effects of partial employment job search on exits to good jobs, while increasing the effects of partial employment on bad jobs. Comparison of the naive estimates in Table 4 with the preferred estimates in Table 2 indicate a positive selection bias in the estimated effects of underemployed job search on transitions to high quality employment, and a negative selection bias in the estimated effects of underemployed job search on transitions to low quality employment. This is also what we found when looking directly at the estimated correlation of the unobserved heterogeneity parameters in Table 3.

In our model, we find a positive and significant effect of ongoing partial benefits on transitions to employment. In an extended model, the on-program effect is examined in more detail: we allow the on-program effect of partial benefits to vary according to the duration of partial employment, by including a set of dummy variables $d^{p}=\left\{d_{1}^{p}, \ldots, d_{5}^{p}\right\}$, indicating the duration of the current spell of part-time work. After the $5^{\text {th }}$ month, on-program effects are assumed to be constant. As we simultaneously model transitions back from part-time work to full time unemployment, the model should in principle be able to account for dynamic selection over the course of part-time work.

Estimates are shown in Table 5. The positive on-program effects of partial employment appear to be driven mainly by transitions in the first month of part-time work. This could reflect employers using a short period of partial unemployment as a screening device when recruiting from unemployment. For good jobs, there are no significant effects of ongoing part time work after the first month. For transitions to bad jobs, the on-program effect of partial employment remains positive in the second month. After the second month, there are no significant effects of ongoing part-time work on transitions to regular employment. In other words, we find no lock-in effects of partial employment even when allowing the effect to vary with duration of part-time work. Looking at non-work transitions however, we do find evidence of lock-in effects: Being partially employed rather than being a full time unemployed job seeker reduces the hazard to ALMP and other benefits; the effect increases in absolute value with the duration of part-time work. In addition, we find indications of negative duration dependence in transitions back to full time unemployment from subsidized part-time work, consistent with part-time employment becoming more stable with tenure.

As discussed in section 2, the measure of job-quality based on total labor earnings three years after leaving unemployment will capture the extent to which the initial job can offer opportunities of career advancement. By looking three years ahead, we would expect the measure of job quality to better reflect any 
Table 5: On-program duration

\begin{tabular}{lcccccc}
\hline \hline & $(1)$ & $(2)$ & $(3)$ & $(4)$ & $(5)$ & $(6)$ \\
Variable & Good Job & Bad Job & PT Work & ALMP & Other Ben & To FTU \\
\hline PT (on), 1 & $1.47^{* * *}$ & $1.682^{* * *}$ & & $.809^{* * *}$ & .83 & \\
& $(5.303)$ & $(8.115)$ & & $(-3.312)$ & $(-1.63)$ & \\
PT (on), 2 & .945 & $1.17^{* *}$ & & $.496^{* * *}$ & $.565^{* * *}$ & $.825^{* * *}$ \\
& $(-.604)$ & $(2.012)$ & & $(-7.505)$ & $(-4.043)$ & $(-5.922)$ \\
PT (on), 3 & .914 & 1.05 & $.412^{* * *}$ & $.475^{* * *}$ & $.739^{* * *}$ \\
& $(-.781)$ & $(.521)$ & & $(-7.353)$ & $(-4.28)$ & $(-7.013)$ \\
PT (on), 4 & 1.043 & .925 & & $.387^{* * *}$ & $.447^{* * *}$ & $.699^{* * *}$ \\
& $(.325)$ & $(-.7)$ & & $(-6.756)$ & $(-3.959)$ & $(-6.627)$ \\
PT (on), 5 & 1.15 & .879 & & $.195^{* * *}$ & $.392^{* * *}$ & $.636^{* * *}$ \\
& $(1.147)$ & $(-1.269)$ & & $(-13.227)$ & $(-5.305)$ & $(-8.49)$ \\
PT Work (post) & 1.082 & $1.183^{* *}$ & $2.376^{* * *}$ & $.864^{* * *}$ & 1.021 & \\
& $(1.055)$ & $(2.536)$ & $(21.45)$ & $(-2.938)$ & $(.242)$ & \\
ALMP (on) & $.518^{* * *}$ & $.492^{* * *}$ & $.631^{* * *}$ & & $.351^{* * *}$ & \\
& $(-6.067)$ & $(-6.968)$ & $(-9.865)$ & & $(-8.568)$ & \\
ALMP (post) & $1.217^{* *}$ & 1.084 & $1.323^{* * *}$ & .941 & $.841^{*}$ & 1.012 \\
& $(2.121)$ & $(.995)$ & $(6.558)$ & $(-1.164)$ & $(-1.91)$ & $(.192)$ \\
\hline \hline
\end{tabular}

Note: Table shows estimates from model where on-program effects of partial employment vary with duration of part time work (15 mass points). Exponentiated coefficients, t-values in parentheses.

Table 6: Short term outcomes - year 1

\begin{tabular}{lcccccc}
\hline \hline & $(1)$ & $(2)$ & $(3)$ & $(4)$ & $(5)$ & $(6)$ \\
Variable & Good Job & Bad Job & PT Work & ALMP & Other Ben & To FTU \\
\hline PT Work (on) & $1.359^{* * *}$ & $1.723^{* * *}$ & & $.63^{* * *}$ & $.693^{* * *}$ & \\
& $(4.162)$ & $(7.868)$ & & $(-7.817)$ & $(-3.368)$ & \\
PT Work (post) & $1.191^{* *}$ & $1.347^{* * *}$ & $2.351^{* * *}$ & $.841^{* * *}$ & 1.078 & \\
& $(2.19)$ & $(4.116)$ & $(20.835)$ & $(-3.347)$ & $(.861)$ & \\
ALMP (on) & $.607^{* * *}$ & $.529^{* * *}$ & $.705^{* * *}$ & & $.356^{* * *}$ & \\
& $(-4.168)$ & $(-5.983)$ & $(-7.374)$ & & $(-8.347)$ & \\
ALMP (post) & $1.436^{* * *}$ & 1.106 & $1.475^{* * *}$ & $.824^{* * *}$ & $.804^{* *}$ & $.794^{* * *}$ \\
& $(3.282)$ & $(1.118)$ & $(8.792)$ & $(-2.801)$ & $(-2.19)$ & $(-4.086)$ \\
\hline \hline
\end{tabular}

Note: Table shows estimates from model where the classification of high/low quality employment is based on year 1 after leaving unemployment only (19 mass points). Exponentiated coefficients, t-values in parentheses. 
stepping stone effects of the initial job. In an alternative specification, the classification of good and bad jobs is based on short term outcomes, using only registered earnings the first year after leaving unemployment. Selected estimates are shown in Table 6.

Estimated program effects to transitions other than employment are very similar to those found in the main model specification, which is reassuring as these outcomes are identical in both specification. As before, taking up part time work during job search increases the hazard rate to employment both during and after the program; effects also seem to be larger for low quality jobs than for high quality jobs. While the difference between effects on high and low quality jobs is smaller than what we find in Table 2, overall the estimates appear to be fairly similar when using a more short-term measure of job quality.

To summarize, our estimated models find that subsidized part time work appears to increase transitions to employment, both during and after the end of part time work. This result is somewhat counterintuitive from the point of view of job search theory, where collecting UI while working part time would increase reservation wages, thus have a negative effect on the job hazard rate. An extended model suggests that the positive on-program effects are driven by transitions occurring during the first months of partial employment, consistent with firms using partial employment as a screening device.

Differentiating between high and low quality jobs, effects are stronger for bad jobs than for good jobs. Again, this is somewhat counter to what one would expect from standard job search theory: increased reservation wages relative to the case with full time unemployment should reduce transitions to lower paying

jobs in particular. The differential effects then suggest the presence of additional mechanisms working in the opposite direction. One possibility is that working part time during job search increases the job offer arrival rate compared to full time unemployment. These additional job offers could then be more likely to come from the poor-job segment, for instance if the type of firms where parttime work is most readily available pay less even in regular jobs or offer fewer opportunities for advancement.

\section{Conclusions}

This paper was motivated by the question of whether UI systems should provide coverage to underemployed job seekers. To answer this question, we have used a timing of events approach to estimate effects of underemployed job search taking up part-time work while continuing to look for regular employment rather than remaining full time unemployed on the hazard of finding regular employment. In our model, underemployed job search is found to unambiguously reduce the time to find unsubsidized, regular employment. Relative to the baseline case of full-time unemployment with no experience of part time work during job search, both on-program and post-program effects of part time work on the job finding hazard rates are positive.

As discussed in the introduction, standard job search theory predicts a de- 
cline in the hazard to regular employment for partially employed job-seekers who receive partial UI, as reservation wages increase relative to full time unemployment. The estimated positive on-program effects appear to go against these predictions. Rather, subsidized part-time work appears to serve as a stepping stone towards regular work. Model extensions suggest that the first month of partial employment is especially important in increasing the employment hazard rate. In $81 \%$ of transitions from underemployed job search to regular work, the employer in the part-time job and the regular job are identical, suggesting employers to some extent use part-time work as a screening device when hiring from unemployment.

The data used in this paper allow us to track individuals for several years after they leave registered unemployment. First, this lets us distinguish between finding a job and other exits from registered unemployment. There is no a priori reason why the effects of underemployed job search should be the same on the job finding hazards and the hazards to other, primarily health related benefits. Working part-time while searching for work is found to decrease the hazard rate to other benefits.

Second, the data on later years is used to model differential treatment effects depending on the earnings level of the job. Residual earnings in the years after exits from unemployment are used to define job quality. While underemployed job search is estimated to have positive effects for both job categories, effects are clearly stronger for low quality employment.

We conclude then that the answer to the question asked at the beginning of this paper is yes; UI systems should provide coverage to underemployed job seekers as it unambiguously shortens the duration of unemployment.

\section{Appendix A: Likelihood function}

Setting up the likelihood function, we follow Røed \& Westlie (2012). The probability that individual $i$ makes a transition to state $k$ during time period $t$ is

$$
p_{k}\left(\phi_{k i t}+v_{k i}\right)=\left(1-\exp \left(-\sum_{k \in K_{i t}} \exp \left(\phi_{k i t}+v_{k i}\right)\right)\right) \frac{\exp \left(\phi_{k i t}+v_{k i}\right)}{\sum_{k \in K_{i t}} \exp \left(\phi_{k i t}+v_{k i}\right)}
$$

where $K_{i t}$ is the set of feasible transitions for individual $i$ in period $t$. Define indicator variable $y_{k i t}$ equal to 1 if there is a transition to state $k, 0$ otherwise, and $Y_{i}$ denote the complete set of outcome indicators available for individual $i$. Conditional on the vector of unobserved variables $v_{i}$, the likelihood contribution of individual $i$ can be written 


$$
\begin{aligned}
L_{i}\left(v_{i}\right) & =\prod_{y_{k i t} \in Y_{i}}\left[\prod_{k \in K_{i t}}\left[p_{k}\left(\phi_{k i t}+v_{k i}\right)\right]^{y_{k i t}}\right] \\
& \times\left[\exp \left(-\sum_{k \in K_{i t}} \exp \left(\phi_{k i t}+v_{k i}\right)\right)\right]^{\left(1-\sum_{k \in K_{i t}} y_{k i t}\right)}
\end{aligned}
$$

We integrate out the unobserved heterogeneity $v_{i}$, taking into account the left-truncation problem in our data: Individuals are included in the dataset conditional on having a spell that survives to the first observation point. We assume that inflows to registered unemployment are uniformly distributed within each calendar month. As we never observe exits in the inflow months, we need to make an assumption regarding the duration effect of the inflow month. We assume that it is equal to the effect in the first observed month. For similar reasons, we assume that the calendar time effect in the very first inflow month, December 2002, is equal to the effect of the following month, January 2003. We let $\bar{t}_{i}$ denote the inflow month for individual $i . \phi_{i \bar{t}_{i}}=\left(\phi_{1 i \bar{t}_{i}}, \ldots, \phi_{5 i \bar{t}_{i}}, \phi_{6 i \bar{t}_{i}}\right)$ Then, using Bayes' rule, the density of unobserved heterogeneity conditional on being included in the sample $f\left(v_{i} \mid d \geq 1\right)$ is related to the unconditional density $f\left(v_{i}\right)$ by

$$
f\left(v_{i} \mid d \geq 1\right)=\frac{\operatorname{Pr}\left(\sum_{k} y_{k i \bar{t}_{i}}=0 \mid \phi_{i \bar{t}_{i}}+v_{i}\right)}{E_{v_{i}} \operatorname{Pr}\left(\sum_{k} y_{k i \bar{t}_{i}}=0 \mid \phi_{i \bar{t}_{i}}+v_{i}\right)} f\left(v_{i}\right)
$$

where

$$
\begin{aligned}
\operatorname{Pr}\left(\sum_{k} y_{k i \bar{t}_{i}}=0 \mid \phi_{i \bar{t}_{i}}+v_{i}\right) & =\int_{0}^{1} \exp (-(1-s)) \sum_{k} \exp \left(\phi_{k i \bar{t}_{i}}+v_{k i}\right) d s \\
& =\frac{1-\exp \left(-\sum_{k} \exp \left(\phi_{k i \bar{t}_{i}}+v_{k i}\right)\right)}{\sum_{k} \exp \left(\phi_{k i \bar{t}_{i}}+v_{k i}\right)}
\end{aligned}
$$

Let $Q$ be the (a priori unknown) number of support points and let $\left\{v_{l}, q_{l}\right\}, l=$ $1,2, \ldots, Q$ be the associated location vectors and probabilities. In terms of observed variables, the likelihood function is given by

$$
\begin{array}{r}
L=\prod_{i=1}^{N} \sum_{l=1}^{Q} q_{l} \frac{\operatorname{Pr}\left(\sum_{k} y_{k i \bar{t}_{i}}=0 \mid \phi_{i \bar{t}_{i}}+v_{l}\right)}{\sum_{l=1}^{Q} q_{l}\left[\operatorname{Pr}\left(\sum_{k} y_{k i \bar{t}_{i}}=0 \mid \phi_{i \bar{t}_{i}}+v_{l}\right)\right]} L_{i}\left(v_{l}\right), \\
\sum_{l=1}^{Q} q_{l}=1
\end{array}
$$

with $L_{i}\left(v_{l}\right)$ from equation (5) and $\operatorname{Pr}\left(\sum_{k} y_{k i \bar{t}_{i}}=0 \mid \phi_{i \bar{t}_{i}}+v_{i}\right)$ from equation (7).

\section{Appendix B: Full estimation results}

In this section we present the full estimates from the main model. Table 7 contains all estimated parameters minus the coefficients on spell duration, calendar 
time and the distribution of unobserved heterogeneity. The seven education levels are compulsory education only (reference group), some high school, high school graduates, some college, undergraduate degree, graduate degree (MA or $\mathrm{PhD}$ ) and education unknown. The four household types are married, cohabiting with kids, single with children and single without children.

Figure 5 plots estimated calendar time effects for the 6 modeled transitions.

Table 7: Main Model: Estimates

\begin{tabular}{|c|c|c|c|c|c|c|}
\hline Variable & $\begin{array}{c}(1) \\
\text { Good Job }\end{array}$ & $\begin{array}{c}(2) \\
\text { Bad Job }\end{array}$ & $\begin{array}{c}(3) \\
\text { PT Work }\end{array}$ & $\begin{array}{c}(4) \\
\text { ALMP }\end{array}$ & $\begin{array}{c}(5) \\
\text { Other Ben }\end{array}$ & $\begin{array}{c}(6) \\
\text { To FTU }\end{array}$ \\
\hline PT Work (on) & $\begin{array}{c}.228^{* * *} \\
(.07)\end{array}$ & $\begin{array}{c}.615^{* * *} \\
(.085)\end{array}$ & & $\begin{array}{c}-.445^{* * *} \\
(.058)\end{array}$ & $\begin{array}{c}-.355^{* * *} \\
(.111)\end{array}$ & \\
\hline PT Work (post) & $\begin{array}{c}.1 \\
(.071)\end{array}$ & $\begin{array}{c}.334^{* * *} \\
(.086)\end{array}$ & $\begin{array}{c}.879^{* * *} \\
(.039)\end{array}$ & $\begin{array}{c}-.168^{* * *} \\
(.049)\end{array}$ & $\begin{array}{c}.054 \\
(.086)\end{array}$ & \\
\hline ALMP (on) & $\begin{array}{c}-.455^{* * *} \\
(.112)\end{array}$ & $\begin{array}{c}-.59^{* * *} \\
(.118)\end{array}$ & $\begin{array}{c}-.343^{* * *} \\
(.047)\end{array}$ & & $\begin{array}{c}-.956^{* * *} \\
(.125)\end{array}$ & \\
\hline ALMP (post) & $\begin{array}{l}.4^{* * *} \\
(.103)\end{array}$ & $\begin{array}{l}.104 \\
(.101)\end{array}$ & $\begin{array}{c}.396^{* * *} \\
(.044)\end{array}$ & $\begin{array}{c}-.196^{* * *} \\
(.07)\end{array}$ & $\begin{array}{l}-.137 \\
(.103)\end{array}$ & $\begin{array}{c}-.234^{* * *} \\
(.056)\end{array}$ \\
\hline No Ben. & $\begin{array}{c}.674^{* * *} \\
(.053)\end{array}$ & $\begin{array}{c}.827^{* * *} \\
(.052)\end{array}$ & $\begin{array}{c}-.155^{* * *} \\
(.042)\end{array}$ & $\begin{array}{c}-.211^{* * *} \\
(.07)\end{array}$ & $\begin{array}{c}1.986^{* * *} \\
(.066)\end{array}$ & $\begin{array}{c}-.352^{* * *} \\
(.038)\end{array}$ \\
\hline $\operatorname{Ln}(w 0)$ & $\begin{array}{c}1.573^{* * *} \\
(.078)\end{array}$ & $\begin{array}{c}-.658^{* * *} \\
(.077)\end{array}$ & $\begin{array}{c}-.363^{* * *} \\
(.039)\end{array}$ & $\begin{array}{l}-.073 \\
(.049)\end{array}$ & $\begin{array}{c}-.391^{* * *} \\
(.092)\end{array}$ & $\begin{array}{l}.102^{*} \\
(.054)\end{array}$ \\
\hline Female & $\begin{array}{c}-.374^{* * *} \\
(.041)\end{array}$ & $\begin{array}{l}.078^{*} \\
(.043)\end{array}$ & $\begin{array}{l}.28^{* * *} \\
(.027)\end{array}$ & $\begin{array}{c}-.195^{* * *} \\
(.033)\end{array}$ & $\begin{array}{l}.018 \\
(.06)\end{array}$ & $\begin{array}{c}-.403^{* * *} \\
(.035)\end{array}$ \\
\hline Low liq. & $\begin{array}{l}-.1^{* * *} \\
(.037)\end{array}$ & $\begin{array}{c}-.191^{* * *} \\
(.04)\end{array}$ & $\begin{array}{c}-.096^{* * *} \\
(.024)\end{array}$ & $\begin{array}{c}.02 \\
(.031)\end{array}$ & $\begin{array}{l}.23^{* * * *} \\
(.056)\end{array}$ & $\begin{array}{c}.094^{* * *} \\
(.032)\end{array}$ \\
\hline Qual. & $\begin{array}{l}-.048 \\
(.072)\end{array}$ & $\begin{array}{c}.093 \\
(.066)\end{array}$ & $\begin{array}{c}.133^{* * *} \\
(.041)\end{array}$ & $\begin{array}{c}.01 \\
(.055)\end{array}$ & $\begin{array}{l}.047 \\
(.092)\end{array}$ & $\begin{array}{c}-.115^{* *} \\
(.056)\end{array}$ \\
\hline Ed. lvl 2 & $\begin{array}{l}.26^{* * *} \\
(.067)\end{array}$ & $\begin{array}{c}.212^{* * *} \\
(.072)\end{array}$ & $\begin{array}{l}.184^{* * *} \\
(.041)\end{array}$ & $\begin{array}{l}.009 \\
(.05)\end{array}$ & $\begin{array}{l}-.028 \\
(.084)\end{array}$ & $\begin{array}{c}-.095^{*} \\
(.052)\end{array}$ \\
\hline Ed. lvl 3 & $\begin{array}{c}.135^{* * *} \\
(.05)\end{array}$ & $\begin{array}{c}.683^{* * *} \\
(.059)\end{array}$ & $\begin{array}{c}.133^{* * *} \\
(.031)\end{array}$ & $\begin{array}{l}-.002 \\
(.039)\end{array}$ & $\begin{array}{l}-.08 \\
(.068)\end{array}$ & $\begin{array}{l}-.063 \\
(.041)\end{array}$ \\
\hline Ed. lvl 4 & $\begin{array}{l}.111 \\
(.099)\end{array}$ & $\begin{array}{c}.998^{* * *} \\
(.106)\end{array}$ & $\begin{array}{l}.058 \\
(.066)\end{array}$ & $\begin{array}{l}.141^{*} \\
(.081)\end{array}$ & $\begin{array}{l}-.273^{*} \\
(.163)\end{array}$ & $\begin{array}{c}-.01 \\
(.085)\end{array}$ \\
\hline Ed. lvl 5 & $\begin{array}{l}.37^{* * *} \\
(.058)\end{array}$ & $\begin{array}{c}1.061^{* * *} \\
(.071)\end{array}$ & $\begin{array}{l}.092^{* *} \\
(.036)\end{array}$ & $\begin{array}{c}-.152^{* * *} \\
(.048)\end{array}$ & $\begin{array}{c}-.38^{* * *} \\
(.093)\end{array}$ & $\begin{array}{l}-.06 \\
(.048)\end{array}$ \\
\hline Ed. lvl 6 & $\begin{array}{l}.152^{*} \\
(.088)\end{array}$ & $\begin{array}{c}1.452^{* * *} \\
(.102)\end{array}$ & $\begin{array}{l}-.046 \\
(.06)\end{array}$ & $\begin{array}{c}-.162^{* *} \\
(.078)\end{array}$ & $\begin{array}{c}-.883^{* * *} \\
(.207)\end{array}$ & $\begin{array}{l}.175^{* *} \\
(.083)\end{array}$ \\
\hline Ed. lvl 7 & $\begin{array}{c}-.42^{* * *} \\
(.113)\end{array}$ & $\begin{array}{l}-.114 \\
(.115)\end{array}$ & $\begin{array}{c}-.2^{* * * *} \\
(.06)\end{array}$ & $\begin{array}{c}-.312^{* * *} \\
(.082)\end{array}$ & $\begin{array}{l}-.093 \\
(.128)\end{array}$ & $\begin{array}{l}.202^{* *} \\
(.087)\end{array}$ \\
\hline HH type 1 & $\begin{array}{l}-.064 \\
(.118)\end{array}$ & $\begin{array}{l}.033 \\
(.127)\end{array}$ & $\begin{array}{l}.003 \\
(.075)\end{array}$ & $\begin{array}{l}-.115 \\
(.091)\end{array}$ & $\begin{array}{l}-.155 \\
(.161)\end{array}$ & $\begin{array}{l}-.125 \\
(.097)\end{array}$ \\
\hline HH type 2 & $\begin{array}{l}.116 \\
(.143)\end{array}$ & $\begin{array}{l}-.052 \\
(.153)\end{array}$ & $\begin{array}{l}.104 \\
(.098)\end{array}$ & $\begin{array}{l}-.189 \\
(.117)\end{array}$ & $\begin{array}{l}.068 \\
(.212)\end{array}$ & $\begin{array}{l}.098 \\
(.127)\end{array}$ \\
\hline HH type 3 & $\begin{array}{l}.088 \\
(.155)\end{array}$ & $\begin{array}{l}-.019 \\
(.165)\end{array}$ & $\begin{array}{l}.187^{*} \\
(.105)\end{array}$ & $\begin{array}{c}-.258^{* *} \\
(.127)\end{array}$ & $\begin{array}{c}.047 \\
(.231)\end{array}$ & $\begin{array}{c}.132 \\
(.137)\end{array}$ \\
\hline HH type 4 & $\begin{array}{l}.108 \\
(.133)\end{array}$ & $\begin{array}{l}-.189 \\
(.144)\end{array}$ & $\begin{array}{c}.254^{* * *} \\
(.088)\end{array}$ & $\begin{array}{l}-.135 \\
(.108)\end{array}$ & $\begin{array}{l}.236 \\
(.189)\end{array}$ & $\begin{array}{l}-.023 \\
(.113)\end{array}$ \\
\hline HH size 2 & $\begin{array}{l}-.004 \\
(.101)\end{array}$ & $\begin{array}{l}-.006 \\
(.112)\end{array}$ & $\begin{array}{l}-.001 \\
(.065)\end{array}$ & $\begin{array}{l}.16^{* *} \\
(.079)\end{array}$ & $\begin{array}{c}.095 \\
(.137)\end{array}$ & $\begin{array}{l}.107 \\
(.086)\end{array}$ \\
\hline HH size 3 & $\begin{array}{l}.043 \\
(.13)\end{array}$ & $\begin{array}{l}-.014 \\
(.138)\end{array}$ & $\begin{array}{l}-.019 \\
(.089)\end{array}$ & $\begin{array}{l}.256^{* *} \\
(.105)\end{array}$ & $\begin{array}{l}-.051 \\
(.191)\end{array}$ & $\begin{array}{l}-.15 \\
(.115)\end{array}$ \\
\hline HH size 4 & $\begin{array}{l}.128 \\
(.155)\end{array}$ & $\begin{array}{l}.039 \\
(.164)\end{array}$ & $\begin{array}{l}.114 \\
(.106)\end{array}$ & $\begin{array}{l}.3^{* *} \\
(.127)\end{array}$ & $\begin{array}{l}-.089 \\
(.231)\end{array}$ & $\begin{array}{c}-.279^{* *} \\
(.138)\end{array}$ \\
\hline
\end{tabular}


Table 7 - continued from previous page

\begin{tabular}{|c|c|c|c|c|c|c|}
\hline Variable & Good Job & Bad Job & PT Work & ALMP & Other Ben & To FTU \\
\hline \multirow[t]{2}{*}{ HH size 5} & .11 & .001 & $.285^{* *}$ & .051 & -.406 & $-.272^{*}$ \\
\hline & $(.182)$ & $(.193)$ & $(.123)$ & $(.154)$ & $(.275)$ & $(.159)$ \\
\hline \multirow[t]{2}{*}{ HH size 6} & -.147 & .03 & .171 & -.022 & -.529 & .017 \\
\hline & $(.293)$ & $(.288)$ & $(.178)$ & $(.231)$ & $(.373)$ & $(.238)$ \\
\hline \multirow[t]{2}{*}{ HH size 7} & .481 & .027 & .105 & -.479 & -.564 & -.12 \\
\hline & $(.492)$ & $(.555)$ & $(.366)$ & $(.449)$ & $(.776)$ & $(.77)$ \\
\hline \multirow[t]{2}{*}{ HH size 8} & .583 & 1.039 & -.597 & .423 & -.386 & .858 \\
\hline & $(.862)$ & $(.687)$ & $(.566)$ & $(.834)$ & (1.184) & $(.691)$ \\
\hline \multirow[t]{2}{*}{ Kids - 1} & -.054 & .061 & $-.187^{* * *}$ & .018 & -.167 & -.012 \\
\hline & $(.077)$ & $(.082)$ & $(.051)$ & $(.064)$ & $(.116)$ & $(.066)$ \\
\hline \multirow[t]{2}{*}{ Kids - 2} & -.046 & $.162^{*}$ & $-.198^{* * *}$ & -.018 & -.197 & 0 \\
\hline & $(.089)$ & $(.096)$ & $(.06)$ & $(.075)$ & $(.139)$ & $(.079)$ \\
\hline \multirow[t]{2}{*}{ Kids - 3} & -.043 & -.007 & $-.263^{* * *}$ & $.302^{* *}$ & .239 & .094 \\
\hline & $(.145)$ & $(.15)$ & $(.092)$ & $(.117)$ & $(.208)$ & $(.118)$ \\
\hline \multirow[t]{2}{*}{ Kids - 4} & -.061 & -.271 & -.249 & $.47^{* *}$ & .414 & -.274 \\
\hline & $(.324)$ & $(.317)$ & $(.187)$ & $(.231)$ & $(.355)$ & $(.271)$ \\
\hline \multirow[t]{2}{*}{ Kids - 5} & -.815 & -.681 & .141 & .113 & .365 & -.02 \\
\hline & $(.665)$ & $(.651)$ & $(.431)$ & $(.751)$ & $(.902)$ & $(.784)$ \\
\hline \multirow[t]{2}{*}{ Age 26} & -.222 & .044 & -.045 & .147 & .336 & .177 \\
\hline & $(.135)$ & $(.151)$ & $(.084)$ & $(.151)$ & $(.264)$ & $(.123)$ \\
\hline \multirow[t]{2}{*}{ Age 27} & -.215 & -.047 & -.111 & .009 & .404 & .081 \\
\hline & $(.134)$ & $(.154)$ & $(.087)$ & $(.157)$ & $(.264)$ & $(.129)$ \\
\hline \multirow[t]{2}{*}{ Age 28} & -.186 & -.082 & -.007 & .059 & .38 & .098 \\
\hline & $(.131)$ & $(.153)$ & $(.087)$ & $(.155)$ & $(.26)$ & $(.125)$ \\
\hline \multirow[t]{2}{*}{ Age 29} & $-.336^{* *}$ & -.044 & -.04 & .112 & .285 & .066 \\
\hline & $(.132)$ & $(.151)$ & $(.086)$ & $(.153)$ & $(.261)$ & $(.125)$ \\
\hline \multirow[t]{2}{*}{ Age 30} & $-.322^{* *}$ & -.032 & -.03 & .109 & .163 & .148 \\
\hline & $(.131)$ & $(.15)$ & $(.085)$ & $(.151)$ & $(.265)$ & $(.123)$ \\
\hline \multirow[t]{2}{*}{ Age 31} & $-.28^{* *}$ & .012 & -.104 & -.005 & .097 & .06 \\
\hline & $(.13)$ & $(.149)$ & $(.085)$ & $(.154)$ & $(.266)$ & $(.125)$ \\
\hline \multirow[t]{2}{*}{ Age 32} & $-.447^{* * *}$ & -.152 & -.079 & .24 & $.459^{*}$ & .064 \\
\hline & (.133) & $(.151)$ & $(.086)$ & $(.15)$ & $(.259)$ & $(.124)$ \\
\hline \multirow[t]{2}{*}{ Age 33} & $-.551^{* * *}$ & -.219 & -.109 & .136 & .345 & .124 \\
\hline & (.133) & $(.153)$ & $(.085)$ & $(.151)$ & $(.26)$ & $(.124)$ \\
\hline \multirow[t]{2}{*}{ Age 34} & $-.453^{* * *}$ & -.245 & -.125 & .143 & $.6^{* *}$ & .189 \\
\hline & (.132) & $(.154)$ & $(.087)$ & $(.152)$ & $(.257)$ & $(.125)$ \\
\hline Age 35 & $-.544^{* * *}$ & -.135 & -.083 & .129 & .303 & .098 \\
\hline & $(.135)$ & $(.153)$ & $(.087)$ & $(.154)$ & $(.267)$ & $(.124)$ \\
\hline Age 36 & $-.694^{* * *}$ & -.217 & -.144 & .192 & .371 & .032 \\
\hline & $(.138)$ & $(.156)$ & $(.088)$ & $(.152)$ & $(.264)$ & $(.128)$ \\
\hline Age 37 & $-.729^{* * *}$ & -.259 & -.037 & $.261^{*}$ & .308 & .056 \\
\hline & $(.14)$ & $(.157)$ & $(.087)$ & $(.151)$ & $(.26)$ & $(.126)$ \\
\hline Age 38 & $-.665^{* * *}$ & -.044 & -.084 & $.28^{*}$ & .302 & .123 \\
\hline & $(.14)$ & $(.156)$ & $(.088)$ & $(.151)$ & $(.268)$ & $(.126)$ \\
\hline Age 39 & $-.71^{* * *}$ & -.194 & -.023 & .187 & .375 & $.241^{*}$ \\
\hline & $(.14)$ & $(.16)$ & $(.088)$ & $(.153)$ & $(.266)$ & $(.128)$ \\
\hline Age 40 & $-.68^{* * *}$ & -.085 & .017 & $.303^{* *}$ & .404 & .133 \\
\hline & $(.143)$ & $(.159)$ & $(.089)$ & $(.153)$ & $(.267)$ & $(.129)$ \\
\hline Age 41 & $-.717^{* * *}$ & -.13 & -.026 & $.285^{*}$ & .194 & .14 \\
\hline & $(.144)$ & $(.162)$ & $(.089)$ & $(.155)$ & $(.276)$ & $(.129)$ \\
\hline Age 42 & $-.771^{* * *}$ & -.014 & -.014 & .194 & .098 & .072 \\
\hline & $(.145)$ & $(.162)$ & $(.091)$ & $(.157)$ & $(.282)$ & $(.135)$ \\
\hline Age 43 & $-.813^{* * *}$ & .017 & .009 & .173 & .437 & .149 \\
\hline & $(.15)$ & $(.164)$ & $(.093)$ & $(.158)$ & $(.274)$ & $(.134)$ \\
\hline & & & & & Continue & next pag \\
\hline
\end{tabular}


Table 7 - continued from previous page

\begin{tabular}{|c|c|c|c|c|c|c|}
\hline Variable & Good Job & Bad Job & PT Work & ALMP & Other Ben & To FTU \\
\hline Age 44 & $\begin{array}{c}-.858^{* * *} \\
(.152)\end{array}$ & $\begin{array}{l}-.075 \\
(.168)\end{array}$ & $\begin{array}{l}-.017 \\
(.093)\end{array}$ & $\begin{array}{l}.221 \\
(.158)\end{array}$ & $\begin{array}{l}.375 \\
(.276)\end{array}$ & $\begin{array}{c}.096 \\
(.133)\end{array}$ \\
\hline Age 45 & $\begin{array}{c}-1.017^{* * *} \\
(.156)\end{array}$ & $\begin{array}{l}.145 \\
(.165)\end{array}$ & $\begin{array}{l}-.058 \\
(.093)\end{array}$ & $\begin{array}{l}.279^{*} \\
(.158)\end{array}$ & $\begin{array}{l}.365 \\
(.279)\end{array}$ & $\begin{array}{l}.075 \\
(.137)\end{array}$ \\
\hline Age 46 & $\begin{array}{c}-.929 * * * \\
(.154)\end{array}$ & $\begin{array}{l}.012 \\
(.167)\end{array}$ & $\begin{array}{l}-.062 \\
(.093)\end{array}$ & $\begin{array}{l}.194 \\
(.162)\end{array}$ & $\begin{array}{l}.572^{* *} \\
.275)\end{array}$ & $\begin{array}{l}.107 \\
(.137)\end{array}$ \\
\hline Age 47 & $\begin{array}{c}-.917^{* * *} \\
(.155)\end{array}$ & $\begin{array}{l}.022 \\
(.169)\end{array}$ & $\begin{array}{l}-.081 \\
(.094)\end{array}$ & $\begin{array}{l}.168 \\
(.162)\end{array}$ & $\begin{array}{l}.537^{*} \\
(.276)\end{array}$ & $\begin{array}{l}.089 \\
(.138)\end{array}$ \\
\hline Age 48 & $\begin{array}{c}-.991^{* * *} \\
(.159)\end{array}$ & $\begin{array}{l}.002 \\
(.171)\end{array}$ & $\begin{array}{l}-.026 \\
(.096)\end{array}$ & $\begin{array}{c}.25 \\
(.168)\end{array}$ & $\begin{array}{l}.534^{*} \\
(.276)\end{array}$ & $\begin{array}{l}.029 \\
(.139)\end{array}$ \\
\hline Age 49 & $\begin{array}{c}-1.237^{* * *} \\
(.167)\end{array}$ & $\begin{array}{l}-.102 \\
(.173)\end{array}$ & $\begin{array}{c}-.163^{*} \\
(.097)\end{array}$ & $\begin{array}{l}.298^{*} \\
(.165)\end{array}$ & $\begin{array}{l}.443 \\
(.285)\end{array}$ & $\begin{array}{l}.159 \\
(.141)\end{array}$ \\
\hline Age 50 & $\begin{array}{c}-1.308^{* * *} \\
(.172)\end{array}$ & $\begin{array}{l}-.195 \\
(.176)\end{array}$ & $\begin{array}{l}.071 \\
(.096)\end{array}$ & $\begin{array}{l}.46^{* * *} \\
(.158)\end{array}$ & $\begin{array}{l}.482^{*} \\
(.279)\end{array}$ & $\begin{array}{l}-.106 \\
(.142)\end{array}$ \\
\hline Age 51 & $\begin{array}{c}-1.254^{* * *} \\
(.167)\end{array}$ & $\begin{array}{l}-.124 \\
(.176)\end{array}$ & $\begin{array}{c}.12 \\
(.095)\end{array}$ & $\begin{array}{l}.145 \\
(.165)\end{array}$ & $\begin{array}{l}.616^{* *} \\
(.275)\end{array}$ & $\begin{array}{l}-.072 \\
(.135)\end{array}$ \\
\hline Age 52 & $\begin{array}{c}-1.363^{* * *} \\
(.182)\end{array}$ & $\begin{array}{l}.027 \\
(.177)\end{array}$ & $\begin{array}{l}.041 \\
(.099)\end{array}$ & $\begin{array}{l}.289^{*} \\
(.165)\end{array}$ & $\begin{array}{c}.703^{* *} \\
(.28)\end{array}$ & $\begin{array}{l}.009 \\
(.141)\end{array}$ \\
\hline Age 53 & $\begin{array}{c}-1.376^{* * *} \\
(.176)\end{array}$ & $\begin{array}{l}.152 \\
(.176)\end{array}$ & $\begin{array}{c}.043 \\
.098)\end{array}$ & $\begin{array}{l}.232 \\
(.165)\end{array}$ & $\begin{array}{l}.432 \\
(.286)\end{array}$ & $\begin{array}{l}.043 \\
(.147)\end{array}$ \\
\hline Age 54 & $\begin{array}{c}-1.482^{* * *} \\
(.187)\end{array}$ & $\begin{array}{l}.066 \\
(.181)\end{array}$ & $\begin{array}{l}.046 \\
(.101)\end{array}$ & $\begin{array}{l}.316^{*} \\
(.165)\end{array}$ & $\begin{array}{l}.536^{*} \\
(.292)\end{array}$ & $\begin{array}{l}.027 \\
(.148)\end{array}$ \\
\hline Age 55 & $\begin{array}{c}-1.714^{* * *} \\
(.2)\end{array}$ & $\begin{array}{l}-.043 \\
(.185)\end{array}$ & $\begin{array}{l}-.084 \\
(.105)\end{array}$ & $\begin{array}{l}.048 \\
(.177)\end{array}$ & $\begin{array}{c}.906^{* * * *} \\
(.281)\end{array}$ & $\begin{array}{l}.086 \\
(.147)\end{array}$ \\
\hline Age 56 & $\begin{array}{c}-1.436^{* * *} \\
(.251)\end{array}$ & $\begin{array}{c}-.14 \\
(.214)\end{array}$ & $\begin{array}{l}-.026 \\
(.125)\end{array}$ & $\begin{array}{l}.301 \\
(.191)\end{array}$ & $\begin{array}{l}.195 \\
(.341)\end{array}$ & $\begin{array}{l}.257 \\
(.167)\end{array}$ \\
\hline Age 57 & $\begin{array}{c}-3.444^{* * *} \\
(1.036)\end{array}$ & $\begin{array}{c}-.732^{*} \\
(.383)\end{array}$ & $\begin{array}{c}.2 \\
(.217)\end{array}$ & $\begin{array}{c}-.14 \\
(.311)\end{array}$ & $\begin{array}{c}.02 \\
(.488)\end{array}$ & $\begin{array}{l}.068 \\
(.238)\end{array}$ \\
\hline
\end{tabular}

Note: Table shows full estimates from the model of the main model, containing 18 mass points in the distribution of $v$. The seven education levels are compulsory education only (reference group), some high school, high school graduates, some college, undergraduate degree, graduate degree (MA or PhD) and education unknown. The household types are single without children (reference group), married without children (type 1), married with children (type 2) cohabiting, with kids (type 3) and single with children (type 4). "HH size" and "Kids" are indicators for number of family members and the number of children under 18: HH size 8 indicates 8 or more household members, Kids 5 indicates 5 or more children under age 18 . 
Figure 5: Calendar time effects - main model specification
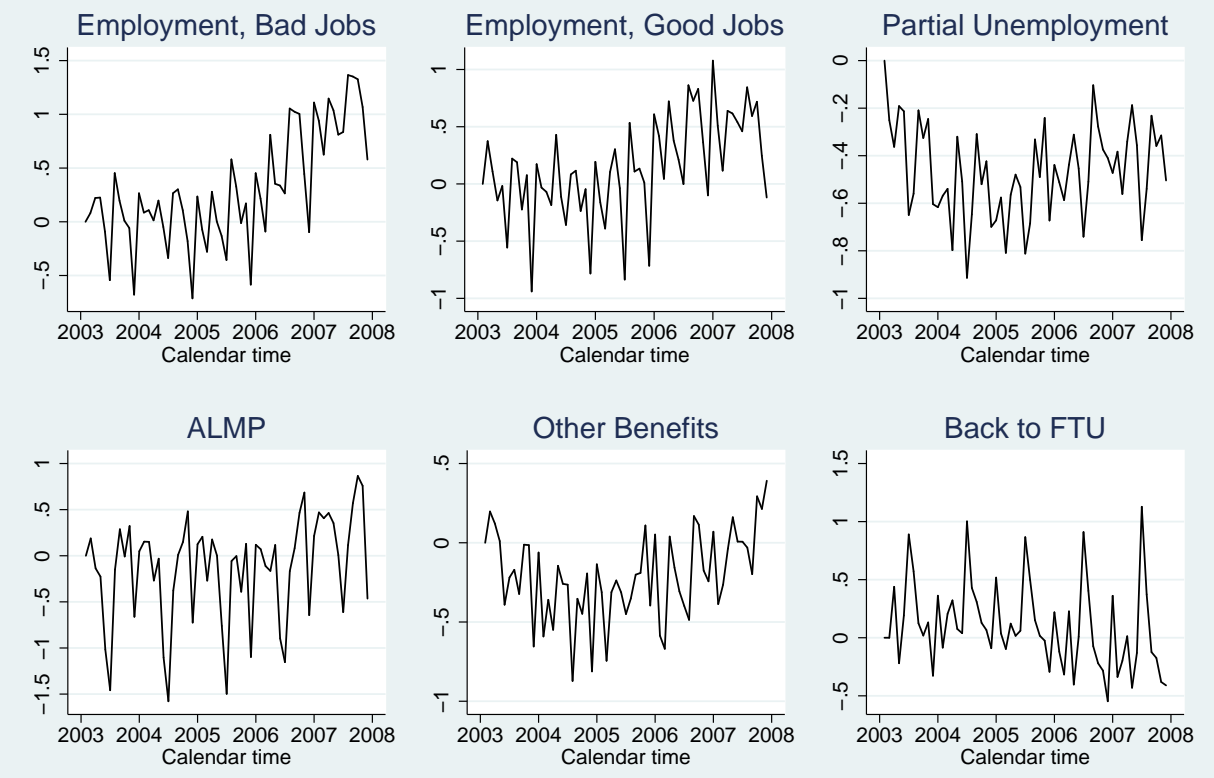

Note: Figure plots estimated calendar time effects.

\section{References}

Abbring, J. H. \& Van den Berg, G. J. (2003), 'The nonparametric identification of treatment effects in duration models', Econometrica 71(5), 1491-1517.

Brinch, C. N. (2007), 'Nonparametric identification of the mixed hazards model with time-varying covariates', Econometric Theory 23(02), 349-354.

Cahuc, P. \& Carcillo, S. (2011), 'Is short-time work a good method to keep unemployment down?'.

Ek, S. \& Holmlund, B. (2011), 'Part-time unemployment and optimal unemployment insurance'.

Gaure, S., Røed, K. \& Zhang, T. (2007), 'Time and causality: A Monte Carlo assessment of the timing-of-events approach', Journal of Econometrics 141(2), 1159-1195. 
Heckman, J. J. \& Singer, B. (1984), 'A method for minimizing the impact of distributional assumptions in econometric models for duration data', Econometrica 52(2), 271-320.

Hijzen, A. \& Martin, S. (2013), 'The role of short-time work schemes during the global financial crisis and early recovery: a cross-country analysis', IZA Journal of Labor Policy 2(5).

Kyyrä, T. (2010), 'Partial unemployment insurance benefits and the transition rate to regular work', European Economic Review 54(7), 911-930.

Kyyrä, T., Parrotta, P. \& Rosholm, M. (2013), 'The effect of receiving supplementary UI benefits on unemployment duration', Labour Economics $\mathbf{2 1}(\mathrm{C}), 122-133$.

McCall, B. P. (1994), 'Identifying state dependence in duration models. american statistical association 1994', Proceedings of the Business and Economics Section 14.

Røed, K. \& Westlie, L. (2012), 'Unemployment insurance in welfare states: the impacts of soft duration constraints', Journal of the European Economic Association 10(3), 518-554.

Van den Berg, G. J. (2001), 'Duration models: specification, identification and multiple durations', Handbook of econometrics 5, 3381-3460. 